\title{
National Survey of Medication Safety Practice: Patient Education, Quality Process and Risk Management at Primary Healthcare Centers/Community Pharmacies in Riyadh, Saudi Arabia
}

\author{
Yousef Ahmed Alomi*, (iD) The Past Gen- \\ eral Manager of General Administration \\ of Pharmaceutical Care, Head, National \\ Clinical Pharmacy and Pharmacy Practice, \\ Head, Pharmacy R \& D Administration, \\ Ministry of Health, Riyadh-11392, SAUDI \\ ARABIA. \\ Zainab Abdulmunem Almuallem, Saudi \\ Food and Drug Authority, Riyadh, SAUDI \\ ARABIA. \\ Manar Mohammed Alslim, Staff Phar- \\ macist, Prince Sultan Military Medical City, \\ Riyadh, SAUDI ARABIA. \\ Khulud Abdulrahman Alamoudi, \\ Narcotic in-charge, Alhammadi Hospital, \\ Riyadh, SAUDI ARABIA. \\ Adel Mehmas H. Alragas, Medical \\ City-king Saud University, Riyadh, SAUDI \\ ARABIA. \\ Rana Mohammed Alslim, Staff Phar- \\ macist, Ministry of Health, Riyadh, SAUDI \\ ARABIA. \\ Correspondence: \\ Dr. Yousef Ahmed Alomi, Bsc. Pharm, \\ MSc. Clin Pharm, BCPS, BCNSP, DiBA, \\ The Past General Manager of General Ad- \\ ministration of Pharmaceutical Care, Head \\ National Clinical Pharmacy and Pharmacy \\ Practice, Head, Pharmacy R \& D Adminis- \\ tration, Ministry of Health, Riyadh- 11392, \\ SAUDI ARABIA.
}

Phone no: +966504417712

E-mail: yalomi@gmail.com

Received: 20-10-2018;

Accepted: 4-11-2018

Copyright: $\odot$ the author(s),publisher and licensee Pharmacology, Toxicology and Biomedical Reports. This is an open-access article distributed under the terms of the Creative Commons Attribution NonCommercial License, which permits unrestricted non-commercial use, distribution, and reproduction in any medium, provided the original work is properly cited.

This is an open access article distributed under the terms of the Creative Commons Attribution-NonCommercial-ShareAlike 4.0 License

\begin{tabular}{|c|c|}
\hline \multicolumn{2}{|c|}{ Access this article online } \\
\hline & www.ptbreports.org \\
\hline & DOI: \\
\hline
\end{tabular}

\begin{abstract}
Objective: To explore the national medication safety practice such as patient education, quality process and risk management at primary healthcare centers (PHCs) and community pharmacies (CPs) in Riyadh city, Kingdom of Saudi Arabia. Methods: This is a four-month cross-sectional medication safety practice survey conducted at PHC pharmacies and CPs in Riyadh city. The survey consisted of the modified version of the Medication Safety Self-Assessment ${ }^{\circledR}$ for Community/Ambulatory Pharmacy from the Institute of Safe Medication Practice (ISMP). The survey consisted of a demographic section and 10 domains with 198 questions. The domains included questions on patient information; drug information; communication of drug orders and other drug information; drug labeling and packaging and nomenclature; use of devices; environmental factors; staff competency and education; patient education; quality processes; and risk management domain. In this study, we emphasized on patient education, quality process and risk management; it is a finding from medication safety self-assessment for community/ambulatory pharmacy in Riyadh city. Results: The survey was distributed to $13 \mathrm{PHC}$ pharmacies and $23 \mathrm{CPs}$. The average score of all ISMP-self assessment of medication safety items at PHCs was $2.75 \pm 0.36$ (54.94\%) (95\% confidence interval $(95 \% \mathrm{Cl})=2.55-2.95 ; P<0.05$; range $=2.04-3.38)$. The average score of all ISMP-self assessment of medication safety items at CPs was $3.14 \pm 0.42(62.86 \%)$ (95\% Cl=2.90-4.38; $P<0.05$; range $=2.40-3.88)$. The average score of patient education at PHCs was $3.04 \pm 0.365(60.8 \%)(95 \% \mathrm{Cl}=2.89-3.19 ; P<0.05$; range $=2.00-3.73)$ and $\mathrm{CPs}$, it was $3.73 \pm 0.29$ (74.6\%) (95\% Cl=3.61-3.85; $P<0.05$; range=3.11-4.22). The average score of quality processes and risk management at $\mathrm{PHCs}$ was $2.76 \pm 0.35$ (55.2\%) $(95 \% \mathrm{Cl}=2.64-2.88 ; P<0.05$; range $=2.09-3.50)$ and at $\mathrm{CPs}$, it was $3.20 \pm 0.38(64 \%)(95 \% \mathrm{Cl}=3.07-3.33 ; P<0.05$; range $=2.47-3.89)$. Conclusion: The implementation of patient education and quality processes and risk management at PHCs and CPs were inadequate. Targeting to improve all meditations safety assessment tools at PHCs and CPs is highly recommended in the Kingdom of Saudi Arabia.
\end{abstract}

Key words: Medication, Safety, Education, Quality, Risk Management, Primary Healthcare Centers, Community Pharmacies, Riyadh, Saudi Arabia.

\section{INTRODUCTION}

GAPC started the implementation of pharmacy strategic plan in 2012. ${ }^{1}$ The plan covers all healthcare institutions including hospitals and PHCs. Part of this initiative was to implement national quality management standards in the pharmacy practice. During the period 2012-2015, there was a collaboration between pharmacy and quality management administration at the $\mathrm{MOH}$. The partnership was developed to implement the Saudi standards of quality management to cover all healthcare centers and hospital. The Saudi Center for Healthcare Accreditation released the first edition of the standard, which was updated in $2016 .^{2}$ The updated version had necessary elements of medication safety. If the healthcare institutions, particularly hospitals implement all elements of medications safety, then they can obtain the accreditation. Several studies have shown the impact of missing quality management implementation. ${ }^{3-6}$

Medication safety practice at $\mathrm{CPs}$ have not been included in the updated CBAHI standards. In
2016, the first author of this article published a new initiative project of Saudi-Managed Care Pharmacy System. ${ }^{7}$ He suggested implementing new measures for $\mathrm{CPs}$ including medication safety-related issues. The community pharmacies had been missed several the practice standard. The initiation of medication safety practice as the assessment tool of prevention of errors in the PHCs and CPs. Few studies have published the finding of self-assessment tools for hospitals. ${ }^{8,9}$ According to these articles, the score of patient education and quality management factors were $48-68 \%$ and $51-72 \%$, respectively. Another local study conducted during Hajj period showed that the score was $75 \%$ for patient education key element and $63.6 \%$ for quality management. ${ }^{10}$ All previous investigations have been conducted at the hospital pharmacy. However, to the best of our knowledge, there is no study about the selfassessment of medications safety practices with the emphasis of quality factors and risk management. Therefore, in this study, we aimed to ex- 
plore the self-assessment of medications safety: quality and risk management at PHCs and CPs in Riyadh city, Saudi Arabia.

\section{METHODS}

This is a four-month cross-sectional medication safety practice survey conducted at PHCs and CPs in Riyadh city. The survey consisted of the modified version of the Medication Safety Self-Assessment for Community/Ambulatory Pharmacy from the ISMP. ${ }^{11}$ It consisted of a demographic section and 10 domains with 198 questions. The domains included patient information; drug information; communication of drug orders and other drug information; drug labeling, packaging and nomenclature; use of devices; environmental factors; staff competency and education; patient education; quality processes; and risk management domain. The survey was conducted at PHC pharmacies of $\mathrm{MOH}$ and CPs located in Riyadh city. The responses were collected using 5-point Likert response scale system. The scoring key identified as number (1) was equal to (A): No activity to implement, (2) was equal to (B): Considered, but not implemented, (3) was equal to (C): Partially implemented in some or all areas, (4) was equal to (D): Fully implemented in some areas and (5) was equal to (E): Fully implemented throughout. The survey was distributed to the directors of PHC pharmacies and CPs. The authors distributed the questionnaire and followed-up on a daily basis by physically visiting and by making a telephonic call. The study questionnaire was prepared in an electronic format and it analyzed through survey monkey system and Microsoft Excel version 10. Based on GAPC and CBAHI standards, we suggested some solutions to improve the scores of the medication safety practice and the results of the ISMP self-assessment. ${ }^{1,2}$ The 10 domains were divided into several parts for the sake of analysis, discussion and solution. Part one consisted of patient information and part two consisted of drug information. Part three consisted of medication preparation and dispensing (communication of drug orders and other drug information, drug labeling and packaging and nomenclature) and part four consisted of medication administration (drug standardization, storage and distribution, medication devices acquisition, use and monitoring). Part five consisted of environmental factors, workflow, staffing and staff competency and part six consisted of patient education, quality processes and risk management. In this study, we emphasized on part one; it is the finding from medication safety selfassessment for community/ambulatory pharmacy in Riyadh city.

\section{RESULTS}

The survey was distributed to 13 PHC pharmacies and 23 CPs. Most of the PHCs were types M1 and M3 (4 (30.8\%) and 3 (23.1\%), respectively). Most of the CPs were large (8 (33.3\%)) and medium type (8 (33.3\%)). The majority of PHCs and CPs had obtained accreditation from the Saudi Commission of Health Specialties (7 (70\%) and 20 (87\%), respectively). Most of PHCs dispensed more than 100 prescriptions daily (7 (53.9\%)), whereas most of the CPs dispensed less than 20 prescriptions daily (11 $(45.8 \%))$. Most of the responders in PHCs were female $(9$ (69.2\%)) (4 (30.8\%) were males) and in CPs all were males (25 (100\%)). Majority of the responders in PHCs were Saudi professionals (12 (92.3\%)), whereas all were non-Saudi professionals in CPs $(25(100 \%))$. Most of the responders belonged to the age group of 30-44 years $(9(69.2 \%))$ and most of them in CPs belonged to the age group of $18-29$ years $(15(62.5 \%))$. Most of the responders in PHCs had obtained a diploma or BSc degree in Pharmacy or a Master of Science degree in Clinical Pharmacy (2 (22.2\%), 3 (33.3\%) and $2(22.2 \%)$, respectively). In CPs, majority of them had obtained a BSc degree in Pharmacy $(22(88 \%))$. Most of the pharmacy staff had not obtained accreditation from the Board of Pharmaceutical Specialties (8 (88.9\%) and 21 (91.3\%) working in the PHCs and CPs, respectively) (Tables 1 and 2).

The average score of patient education at PHCs was $3.04 \pm 0.365$ (60.8\%) (95\% CI $=2.89-3.19 ; P<0.05$; range $=2.00-3.73$ ), whereas at CPs, it was $3.73 \pm 0.29$ (74.6\%) (95\% CI=3.61-3.85; $P<0.05$; range=3.11-4.22). The average score quality processes and risk management at PHCs were $2.76 \pm$ $0.35(55.2 \%)(95 \% \mathrm{CI}=2.64-2.88 ; P<0.05$; range $=2.09-3.50)$ while in the $\mathrm{CP}$ was $3.20 \pm 0.38$ (64\%) (95\% CI=3.07-3.33; $P<0.05$; range $=2.47-3.89)$ (Table 3 ). The highest score of the patient education with Core \#16 was obtained for the statement "Pharmacists fully investigate all patient/caregiver concerns and questions about a medication prior to dispensing" $(3.6(72 \%))$ at PHCs, whereas at CPs, the highest score was obtained for the statement "Pharmacists design drug administration schedules that consider the patient's lifestyle and minimize the number of times per day that medications must be taken for patients at high risk for nonadherence with prescribed medications" (4.22 (84.4\%)). The lowest score at PHCs was obtained for the statement "When counseling is provided, the patient's drug container is opened in front of the patient/caregiver to verify the appearance of the medication" $(2.00(40 \%))$, whereas at CPs, the lowest score was obtained for the statement "In as confidential a manner as possible, pharmacists inquire about the patient's understanding of the purpose of new medications and refilled prescriptions" (3.33 (66.6\%)) (Table 4).

At PHCs and CPs, the highest score of the patient education with Core \#17 was obtained for the statement "Pharmacists participate in clinical disease management programs for conditions such as asthma, hypertension, diabetes or hypercholesterolemia" (3.33 (66.6\%) and 3.67 (73.4\%), respectively). The lowest score at PHCs it was obtained for the statement "In the past year, pharmacists have participated in at least one screening clinic locally to promote early detection of disease" $(3.09(61.8 \%))$ and at CPs, it was obtained for the statement "Pharmacists have participated in promoting, facilitating and providing immunizations to the local community to improve public health" (3.24 (64.8\%)) (Table 5). The highest score of quality processes and risk management with Core \#18 was obtained for the statement "Error prevention strategies in the pharmacy target the system, not individual practitioners" (3.00 (60\%)) at PHCs, whereas at CPs, it was obtained for the statement "Pharmacists and technicians are trained in the clinical and administrative procedures for responding to a serious medication error" $(3.63(72.6 \%))$. The lowest score at PHCs was obtained for the statement "In the individual pharmacy or for chains of pharmacies, error rates are not determined or calculated from practitioner error reports and are not used for internal comparisons" $(2.09(41.8 \%))$, whereas at CPs, it was obtained for the statement "Error prevention strategies in the pharmacy target the system, not individual practitioners involved)" (2.68 (53.6\%)) (Table 6).

The highest score of quality processes and risk management with Core \#19 was obtained for the statement "Management and staff pharmacists/ technicians routinely read and use published error experiences from other organizations" $(3.18(63.6 \%))$ at PHCs, whereas at CPs, it was obtained for the statement "A clear definition and examples of medication errors and hazardous situations that should be reported has been established and disseminated to staff $(3.79(75.8 \%))$. The lowest score at PHCs was obtained for the statement "One pharmacist in the individual pharmacy has responsibility for enhancing detection of medication errors, overseeing analysis of their causes and coordinating an effective error reduction plan" $(2.33(46.6 \%))$, whereas at CPs, it was obtained for the statement "Pharmacy management supports practitioner reporting to external reporting programs such as the USP-ISMP Medication Errors Reporting Program and the CDC Vaccine Adverse Reaction Reporting System" (2.58 (51.6\%)) (Table 7). The highest score of quality processes and risk management with Core \#20 was obtained for the statement "A pharmacist verifies all over-the-counter insulin with the patient/caregiver before the product is dispensed" (3.5 (70\%) at PHCs and 3.89 (77.8\%) at CPs). 
Table 1: Demographic hospital information.

\section{Region of work}

M1: Referral PHCS for post graduate studies services up to 32,000 of population.

M2: Referral internal sector PHCS services up to 32,000 of population.

M3: Referral PHCS services internal cities up to 44,000 of population.

M4: Referral PHCS services internal cities with housing up to 32,000 of population

M5: Referral external sector PHCS services up to16, 000 of population.

M6: Referral external sector with housing PHCS services up to 16,000 of population.

M7: Referral small PHCS services up to 32,000 of population.

A0: primary care centers located at more than $35 \mathrm{Km}$ distance and services 2,000-9,000 of population

B1: Big primary care center located at outside cities and within, $35 \mathrm{Km}$ distance from referral PHCS, services $15,000-25,000$ of population.

B2: Big primary care center located at outside cities and within, $35 \mathrm{Km}$ distance from referral PHCS, services $12,000-15,000$ of population.

B3: Big primary care center located at outside cities and within, $35 \mathrm{Km}$ distance from referral PHCS, services 3,000-12,000 of population.

Other (please specify)

Answered question

Skipped question

The hospital accreditation

\section{CIBAHI}

Joint Commotion USA

Canada

Saudi commission of health accreditation

Non accredited

Answered question

Skipped question

\section{Number of prescriptions per day}

No more than 20 prescriptions

No more than 30 prescriptions

No more than 50 prescriptions

No more than 70 prescriptions

No more than 100 prescriptions

more than 100 prescriptions

100-499 prescriptions

500-999 prescriptions

$=$ or $>1000$ prescriptions

Other (please specify)

Answered question

Skipped question

\begin{tabular}{|c|c|c|c|}
\hline \multicolumn{2}{|c|}{ Primary care centers } & \multicolumn{2}{|c|}{ Community pharmacies } \\
\hline $\begin{array}{c}\text { Response } \\
\text { Count }\end{array}$ & $\begin{array}{l}\text { Response } \\
\text { Percent }\end{array}$ & $\begin{array}{c}\text { Response } \\
\text { Count }\end{array}$ & $\begin{array}{c}\text { Response } \\
\text { Percent }\end{array}$ \\
\hline 4 & $30.8 \%$ & $\begin{array}{c}\text { Super } \\
\text { Pharmacy }\end{array}$ & $7(29.2 \%)$ \\
\hline 0 & $0.0 \%$ & $\begin{array}{c}\text { Large } \\
\text { Pharmacy }\end{array}$ & $8(33.3 \%)$ \\
\hline 3 & $23.1 \%$ & $\begin{array}{l}\text { Medium } \\
\text { Pharmacy }\end{array}$ & $8(33.3 \%)$ \\
\hline 1 & $7.7 \%$ & $\begin{array}{c}\text { Small } \\
\text { Pharmacy }\end{array}$ & $1(4.2 \%)$ \\
\hline 0 & $0.0 \%$ & $\begin{array}{l}\text { Other (please } \\
\text { specify) }\end{array}$ & $0(0.0 \%)$ \\
\hline 0 & $0.0 \%$ & $\begin{array}{l}\text { Answered } \\
\text { question }\end{array}$ & 24 \\
\hline 1 & $7.7 \%$ & $\begin{array}{l}\text { Skipped } \\
\text { question }\end{array}$ & 1 \\
\hline 2 & $15.4 \%$ & & \\
\hline 1 & $7.7 \%$ & & \\
\hline 0 & $0.0 \%$ & & \\
\hline 0 & $0.0 \%$ & & \\
\hline 1 & $7.7 \%$ & & \\
\hline 13 & & & \\
\hline 0 & & & \\
\hline 1 & $10.0 \%$ & 3 & $13.0 \%$ \\
\hline 0 & $0.0 \%$ & 0 & $0.0 \%$ \\
\hline 1 & $10.0 \%$ & 0 & $0.0 \%$ \\
\hline 7 & $70.0 \%$ & 20 & $87.0 \%$ \\
\hline 1 & $10.0 \%$ & 0 & $0.0 \%$ \\
\hline 10 & & 23 & \\
\hline 3 & & 2 & \\
\hline 0 & $0.0 \%$ & 11 & $45.8 \%$ \\
\hline 0 & $0.0 \%$ & 5 & $20.8 \%$ \\
\hline 1 & $7.7 \%$ & 2 & $8.3 \%$ \\
\hline 1 & $7.7 \%$ & 1 & $4.2 \%$ \\
\hline 3 & $23.1 \%$ & 4 & $16.7 \%$ \\
\hline 4 & $30.8 \%$ & 1 & $4.2 \%$ \\
\hline 2 & $15.4 \%$ & 0 & $0.0 \%$ \\
\hline 0 & $0.0 \%$ & 0 & $0.0 \%$ \\
\hline 1 & $7.7 \%$ & 0 & $0.0 \%$ \\
\hline 1 & $7.7 \%$ & 0 & $0.0 \%$ \\
\hline 13 & & 24 & \\
\hline 0 & & 1 & \\
\hline
\end{tabular}




\begin{tabular}{|c|c|c|c|c|}
\hline \multirow[b]{2}{*}{ Gender } & \multicolumn{2}{|c|}{ Primary care centers } & \multicolumn{2}{|c|}{$\begin{array}{c}\text { Community pharma- } \\
\text { cies }\end{array}$} \\
\hline & $\begin{array}{l}\text { Response } \\
\text { Count }\end{array}$ & $\begin{array}{c}\text { Response } \\
\text { Percent }\end{array}$ & $\begin{array}{c}\text { Re- } \\
\text { sponse } \\
\text { Count }\end{array}$ & $\begin{array}{c}\text { Response } \\
\text { Percent }\end{array}$ \\
\hline Female & 9 & $69.2 \%$ & 0 & $0.0 \%$ \\
\hline Male & 4 & $30.8 \%$ & 25 & $100.0 \%$ \\
\hline Answered question & 13 & & 25 & \\
\hline Skipped question & 0 & & 0 & \\
\hline \multicolumn{5}{|l|}{ Nationality } \\
\hline Saudi & 12 & $92.3 \%$ & 0 & $0.0 \%$ \\
\hline Non- Saudi & 1 & $7.7 \%$ & 25 & $100.0 \%$ \\
\hline Answered question & 13 & & 25 & \\
\hline Skipped question & 0 & & 0 & \\
\hline \multicolumn{5}{|l|}{ Age } \\
\hline$<18$ & 1 & $7.7 \%$ & 0 & $0.0 \%$ \\
\hline $18-29$ & 3 & $23.1 \%$ & 15 & $62.5 \%$ \\
\hline $30-44$ & 9 & $69.2 \%$ & 9 & $37.5 \%$ \\
\hline $45-59$ & 0 & $0.0 \%$ & 0 & $0.0 \%$ \\
\hline $60+$ & 0 & $0.0 \%$ & 0 & $0.0 \%$ \\
\hline Answered question & 13 & & 24 & \\
\hline Skipped question & 0 & & 1 & \\
\hline \multicolumn{5}{|l|}{ Academic Qualification (s): } \\
\hline Diploma Pharmacy & 2 & $22.2 \%$ & 1 & $4.0 \%$ \\
\hline Bsc. Pharm & 3 & $33.3 \%$ & 22 & $88.0 \%$ \\
\hline M.S & 0 & $0.0 \%$ & 0 & $0.0 \%$ \\
\hline Msc. Clinical Pharmacy & 2 & $22.2 \%$ & 1 & $4.0 \%$ \\
\hline Pharm.D. & 1 & $11.1 \%$ & 2 & $8.0 \%$ \\
\hline Ph.D & 0 & $0.0 \%$ & 1 & $4.0 \%$ \\
\hline MBA & 0 & $0.0 \%$ & 1 & $4.0 \%$ \\
\hline Pharmacy Residency Two years (R1) & 0 & $0.0 \%$ & 0 & $0.0 \%$ \\
\hline Pharmacy Residency one year (R2) & 0 & $0.0 \%$ & 0 & $0.0 \%$ \\
\hline Fellowship & 0 & $0.0 \%$ & 0 & $0.0 \%$ \\
\hline Other (please specify) & 1 & $11.1 \%$ & 1 & $4.0 \%$ \\
\hline Answered question & 9 & & 25 & \\
\hline Skipped question & 4 & & 0 & \\
\hline \multicolumn{5}{|l|}{ Board of Pharmaceutical Specialty } \\
\hline Board Certified Ambulatory Care Pharmacist (BCACP) & 1 & $11.1 \%$ & 0 & $0.0 \%$ \\
\hline Board Certified Critical Care Pharmacist (BCCCP) & 0 & $0.0 \%$ & 1 & $4.3 \%$ \\
\hline Board Certified Nuclear Pharmacist (BCNP) & 0 & $0.0 \%$ & 0 & $0.0 \%$ \\
\hline Board Certified Nutrition Support Pharmacist (BCNSP) & 0 & $0.0 \%$ & 0 & $0.0 \%$ \\
\hline Board Certified Oncology Pharmacist (BCOP) & 0 & $0.0 \%$ & 0 & $0.0 \%$ \\
\hline Board Certified Pediatric Pharmacy Specialist (BCPPS) & 0 & $0.0 \%$ & 1 & $4.3 \%$ \\
\hline Board Certified Pharmacotherapy Specialists (BCPS) & 0 & $0.0 \%$ & 0 & $0.0 \%$ \\
\hline Board Certified Psychiatric Pharmacist (BCPP) & 0 & $0.0 \%$ & 0 & $0.0 \%$ \\
\hline Non & 8 & $88.9 \%$ & 21 & $91.3 \%$ \\
\hline Answered question & 0 & & 0 & \\
\hline
\end{tabular}




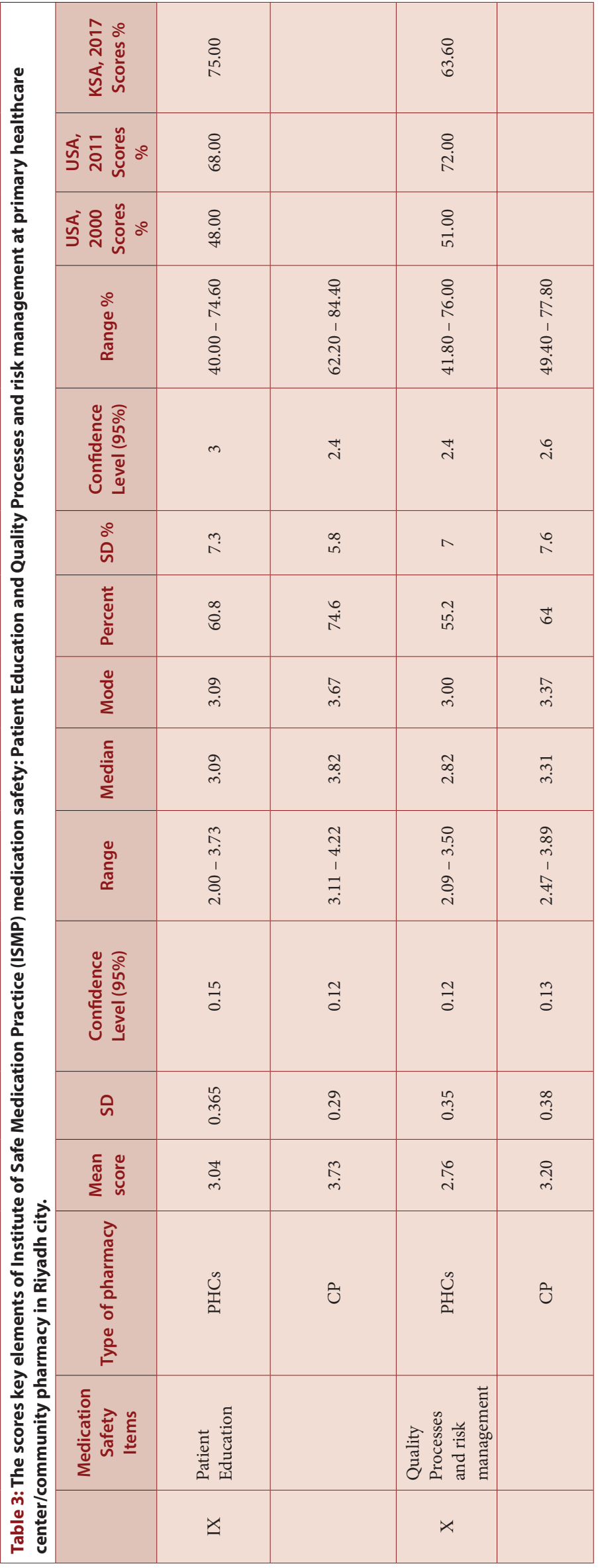

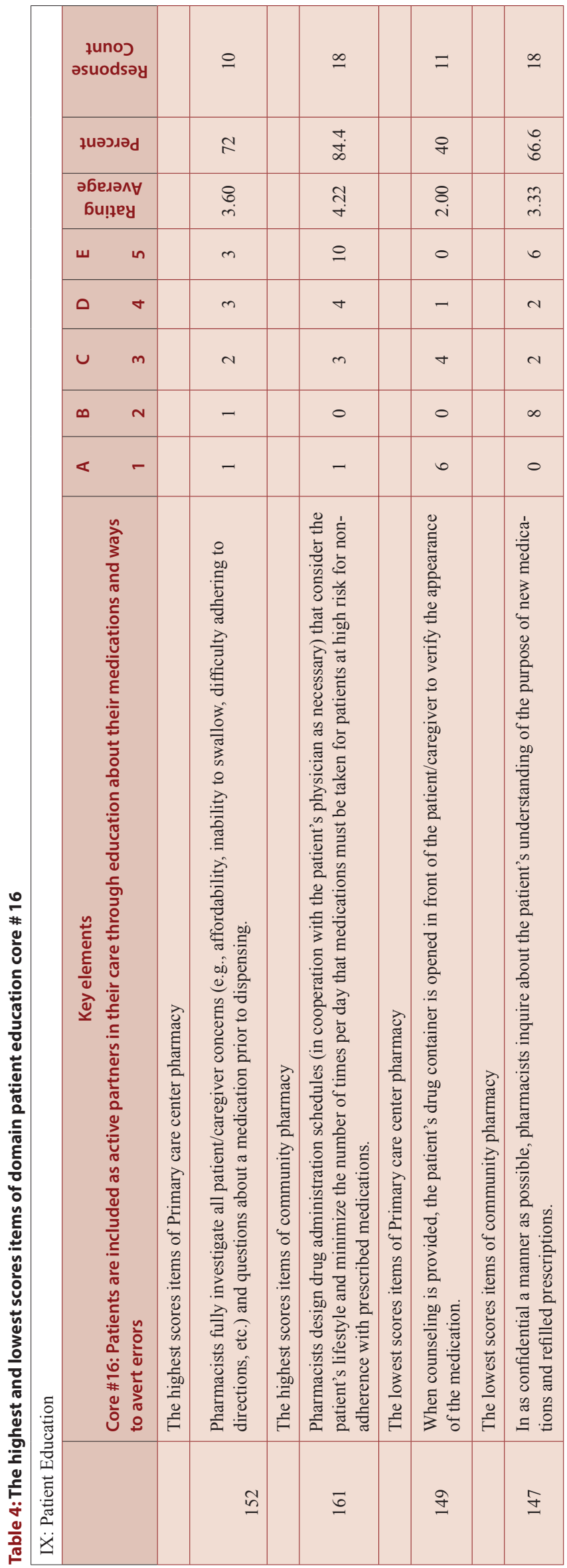




\begin{tabular}{|c|c|c|c|c|c|c|c|c|c|}
\hline \multicolumn{10}{|c|}{ IX: Patient Education } \\
\hline & $\begin{array}{l}\text { Key elements } \\
\text { Core \#17: Pharmacists establish and participate in community-based } \\
\text { disease prevention and monitoring programs to promote health and } \\
\text { ensure appropriate therapy and outcomes of medication use. }\end{array}$ & 1 & 2 & 3 & D & 5 & 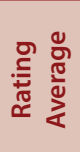 & 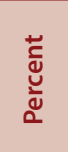 & 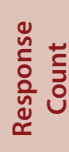 \\
\hline & The highest scores items of Primary care center pharmacy & & & & & & & & \\
\hline 163 & The highest scores items of community pharmacy & & & & & & & & \\
\hline \multirow[t]{2}{*}{163} & $\begin{array}{l}\text { Pharmacists participate in clinical disease management programs for } \\
\text { conditions such as asthma, hypertension, diabetes or hypercholesterolemia. }\end{array}$ & 3 & 0 & 3 & 6 & 6 & 3.67 & 73.4 & 18 \\
\hline & The lowest scores items of Primary care center pharmacy & & & & & & & & \\
\hline 165 & $\begin{array}{l}\text { Pharmacists have participated in promoting, facilitating and providing } \\
\text { immunizations to the local community to improve public health. }\end{array}$ & 1 & 5 & 4 & 3 & 4 & 3.24 & 64.8 & 17 \\
\hline
\end{tabular}

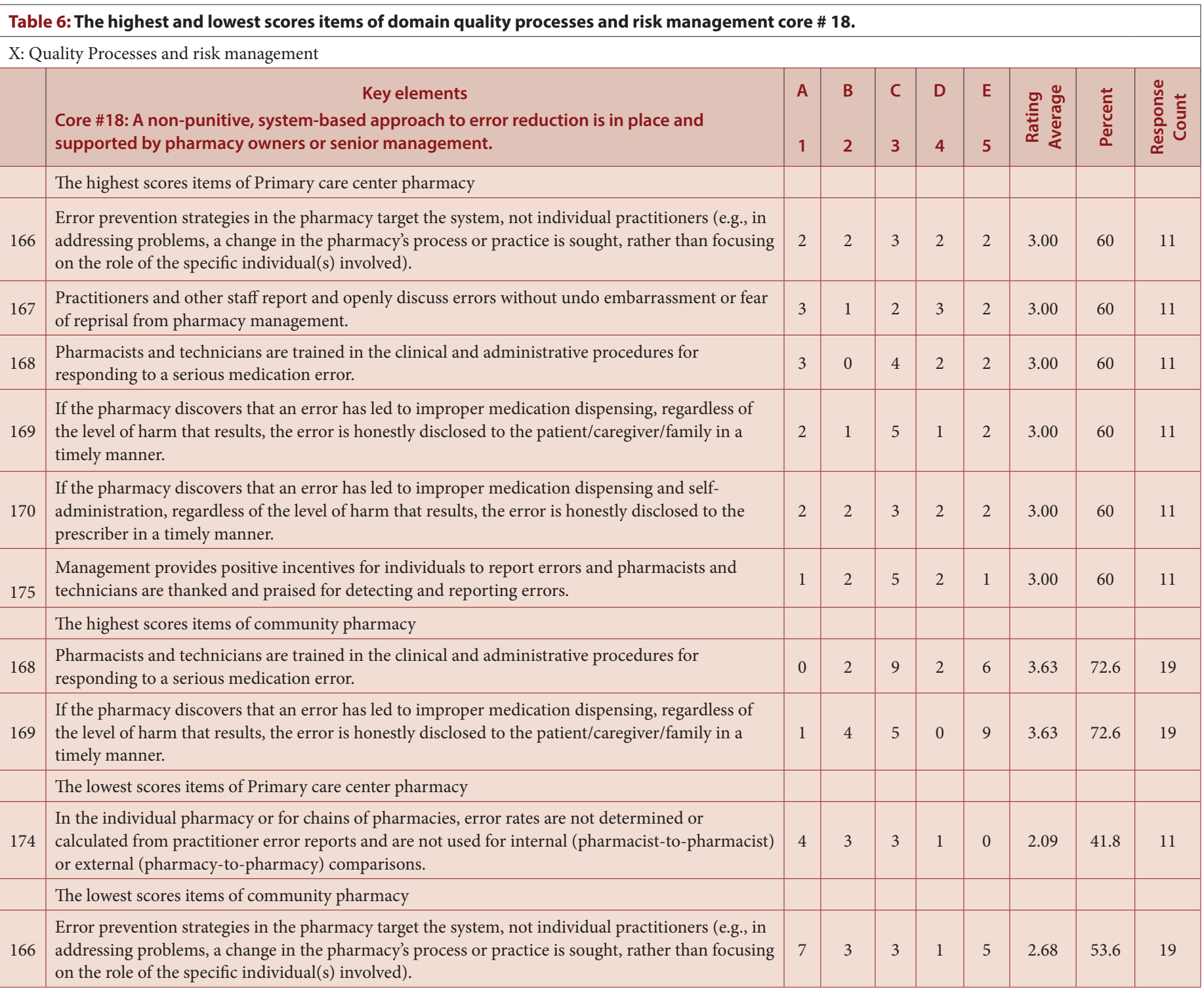




\begin{tabular}{|c|c|c|c|c|c|c|c|c|c|}
\hline \multicolumn{10}{|c|}{ X: Quality Processes and risk management } \\
\hline & $\begin{array}{l}\text { Key elements } \\
\text { Core \#19: Practitioners are stimulated to detect and report errors and teams (or } \\
\text { individual practitioners in small pharmacies) regularly analyze errors that have } \\
\text { occurred within the organization and in other organizations for the purpose of } \\
\text { redesigning systems to best support safe practitioner performance }\end{array}$ & A & 2 & C & 4 & 5 & 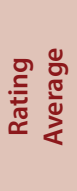 & 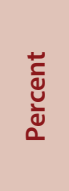 & 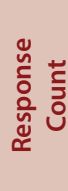 \\
\hline & The highest scores items of Primary care center pharmacy & & & & & & & & \\
\hline \multirow[t]{2}{*}{187} & $\begin{array}{l}\text { Management and staff pharmacists/technicians routinely read and use published error } \\
\text { experiences from other organizations to proactively target improvements in the medica- } \\
\text { tion dispensing process. }\end{array}$ & 1 & 1 & 6 & 1 & 2 & 3.18 & 63.6 & 11 \\
\hline & The highest scores items of community pharmacy & & & & & & & & \\
\hline \multirow[t]{2}{*}{180} & $\begin{array}{l}\text { A clear definition and examples of medication errors and hazardous situations that should } \\
\text { be reported has been established and disseminated to staff. }\end{array}$ & 1 & 3 & 4 & 2 & 9 & 3.79 & 75.8 & 19 \\
\hline & The lowest scores items of Primary care center pharmacy & & & & & & & & \\
\hline \multirow[t]{2}{*}{182} & $\begin{array}{l}\text { One pharmacist in the individual pharmacy has responsibility for enhancing detection of } \\
\text { medication errors, overseeing analysis of their causes and coordinating an effective error } \\
\text { reduction plan (with corporate support as applicable). }\end{array}$ & 4 & 4 & 2 & 0 & 2 & 2.33 & 46.6 & 12 \\
\hline & The lowest scores items of community pharmacy & & & & & & & & \\
\hline 190 & $\begin{array}{l}\text { Pharmacy management supports practitioner reporting to external reporting programs } \\
\text { such as the USP-ISMP Medication Errors Reporting Program and the CDC Vaccine } \\
\text { Adverse Reaction Reporting System. }\end{array}$ & 5 & 4 & 7 & 0 & 3 & 2.58 & 51.6 & 19 \\
\hline
\end{tabular}

\begin{tabular}{|c|c|c|c|c|c|c|c|c|c|}
\hline \multicolumn{10}{|c|}{ X: Quality Processes and risk management } \\
\hline & $\begin{array}{l}\text { Key elements } \\
\text { Core \#20: Simple redundancies that support a system of independent } \\
\text { double checks or an automated verification process are used for } \\
\text { vulnerable parts of the dispensing system to detect and correct serious } \\
\text { errors before they reach patients. }\end{array}$ & 1 & B & C & 4 & E & 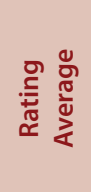 & 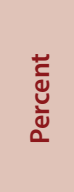 & 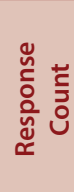 \\
\hline & The highest scores items of Primary care center pharmacy & & & & & & & & \\
\hline \multirow[t]{2}{*}{196} & $\begin{array}{l}\text { A pharmacist verifies all over-the-counter insulin with the patient/caregiver } \\
\text { before the product is dispensed. }\end{array}$ & 0 & 3 & 3 & 3 & 3 & 3.50 & 70 & 12 \\
\hline & The highest scores items of community pharmacy & & & & & & & & \\
\hline \multirow[t]{2}{*}{196} & $\begin{array}{l}\text { A pharmacist verifies all over-the-counter insulin with the patient/caregiver } \\
\text { before the product is dispensed. }\end{array}$ & 0 & 4 & 3 & 2 & 9 & 3.89 & 77.8 & 18 \\
\hline & The lowest scores items of Primary care center pharmacy & & & & & & & & \\
\hline \multirow[t]{2}{*}{ 192B } & $\begin{array}{l}\text { Where electronic prescribing (e.g., prescription sent electronically via com- } \\
\text { puter/hand held device) is available and used, a pharmacist reviews the order } \\
\text { in the computer before generating a label from which the drug order is filled. }\end{array}$ & 5 & 1 & 3 & 2 & 0 & 2.18 & 43.6 & 11 \\
\hline & The lowest scores items of community pharmacy & & & & & & & & \\
\hline 195 & $\begin{array}{l}\text { Both the medication base product and the mixing solution/diluents used } \\
\text { for reconstituted products are checked and documented with initials on the } \\
\text { prescription by at least a pharmacist and one other person }\end{array}$ & 6 & 6 & 2 & 2 & 3 & 2.47 & 49.4 & 19 \\
\hline
\end{tabular}

The lowest score at PHCs was obtained for the statement "Where electronic prescribing is available and used, a pharmacist reviews the order in the computer before generating a label from which the drug order is filled" $(2.18(43.6 \%))$, whereas at CPs, it was obtained for the statement "Both the medication base product and the mixing solution/diluents used for reconstituted products are checked and documented with initials on the prescription by at least a pharmacist and one other person" (2.47 (49.4\%)) (Table 8).

\section{DISCUSSION}

The patient education and quality management programs were goals of the strategic pharmacy at the $\mathrm{MOH}$ in the KSA. ${ }^{1}$ There were separated committees for each project. The committee consisted of representatives from each region to follow the program's implementation at hospitals and PHCs. CPs were not included in both programs. However, the patient education and quality management programs were implemented 
through self-improvement for all primary care center and community pharmacy. We explored both programs as related to medication safety. The results of this study showed that the patient education scores of CPs was better than that of PHCs. This is related to more effort for competition in the pharmacy market. The results regarding CPs were similar to the results of previous international and local studies, whereas the results related to PHCs were lower than that of previous international and regional studies. ${ }^{8-10}$ Because it was newly established. The results of both PHCs and CPs in quality management are almost the same. However, both results were found to be lower than that of previous international and local studies. ${ }^{8-10}$ This is because it was newly established at PHCs and not well developed at CPs.

The lowest score related to patient education at PHCs and CPs were related to some skills in patient counseling. Both demand for education and training courses improve their skills. Moreover, some services need to be added to both types of pharmacies. This includes the clinic for screening the disease and immunization services. Both services are not allowed in the pharmacy law. The law should be updated. The findings of cores \# 18 and \# 19 of the medication safety demand prevention measures and documentation of adverse drug reactions at PHCs and CPs. The national system of medication errors education and training is mandated. The lowest safety score with an emphasis on the quality management at PHCs; that's related to the missing of an electronic prescribing. Most of primary care center pharmacy not started the computerized physician order enter. In the CPs the lowest safety scores was the standardized of extemporaneous preparation; that's excepted because the unified extemporaneous preparations not excised. The PHCs and CPs need more efforts to implement the medication safety assessment tools with emphasis on the patient counseling and quality management system and risk management in the KSA.

\section{CONCLUSION}

Half of medication safety assessments tool with emphasis on the patient counseling and quality management and risk management is not implemented in the PHCs and CPs. Several medication safety tools should be implemented with emphasis on e-prescribing, patient education, risk managements

\section{ACKNOWLEDGEMENT}

I wish to thank directors of primary healthcare pharmacies and community pharmacies for their cooperation and filled the survey.

\section{CONFLICT OF INTEREST}

None

\section{ABBREVIATIONS}

PHCs: Primary healthcare centers; CPs: Community pharmacies; CI: Confidence interval; CBAHI: Saudi Central Board of Accreditation for Healthcare Institutions; ISMP: Institute of Safe Medication Practice; MOH: Ministry of Health; KSA: Kingdom of Saudi Arabia; USA: United States of America.

\section{ORCID ID}

Yousef Ahmed Alomi (D) https://orcid.org/0000-0003-1381-628X

\section{REFERENCES}

1. Alomi YA, Alghamdi SJ, Alattyh RA. Strategic Plan of General Administration of Pharmaceutical Care at Ministry of Health in Saudi Arabia 2012 - 2022. J Pharm Pharm Scien. 2015;1(13):1-8.

2. Medication Management (MM). In: National Hospital Standards. $2^{\text {nd }}$ Edition Saudi Central Board for Accreditation of Healthcare Institutions. 2015;194-211.

3. Chassin MR, Galvin RW. The urgent need to improve health care quality. Institute of Medicine National Roundtable on Health Care Quality. JAMA. 1998;280(11):1000-5.

4. Prabhu KL, Cleghorn MC, Elnahas A, Tse A, Maeda A, Quereshy FA, et al. Is quality important to our patients? The relationship between surgical outcomes and patient satisfaction. BMJ Qual Saf [Internet]. 2018;27(1):48-52.

5. Avedis Donabedian. Evaluating the Quality of Medical Care. Milbank Q. 2005;83(4):691-729

6. Alomi YA, Aldosori N, Alhadab M, Alotaibi NR, Al-Shubbar N, Alotaibi T, et al. The Value of Clinical Pharmacist Consultation Visits at Ministry of Health Hospitals in Saudi Arabia: Intravenous Admixture Services and Pharmacy Total Quality Management. J Pharm Pract Community Med. 2017;3(3).

7. Alomi YA, Alghamdi SJ, Alattyh RA. Saudi Managed Care Pharmacy (SMCP): New Initiative System of MOH Prescriptions Dispensed Through Community Pharmacies. J Pharm Pract Community Med. 2017;3(3).

8. Smetzer JL, Vaida AJ, Cohen MR, Tranum D, Pittman MA, Armstrong CW. Findings from the ISMP Medication Safety Self-Assessment for hospitals. Jt Comm J Qual Saf. 2003;29(11):586-97.

9. Vaida AJ, Smetzer JL, Lamis RL, Cohen MR, Kenward K. Assessing the state of safe medication practices using the ISMP medication safety self assessment ${ }^{\circledR}$ for hospitals: 2000 and 2011. Jt Comm J Qual Patient Saf. 2014;40(2):51-67.

10. Ahmed AY, Adnan YKN, Jamil BM, Abdulraheem BY, Mohammed AJH. National Survey of Hospital Medication Safety Practice during Mass Gathering (Haji2016) in Makkah, Saudi Arabia: Patient Education, Quality Process and Risk Management. J Pharm Pract Community Med [Internet]. 2017;3(4s):1-7.

11. Institute for Safe Medication Practices. 2011 ISMP Medication Safety Self Assessment for Hospitals, Key Definitions. 2011. 